\title{
Classification of Mycobacterium farcinogenes and Mycobacterium senegalense by Immunodiffusion and Thin-layer Chromatography of Long-chain Components
}

\author{
By MALIN RIDELL, ${ }^{1}$ M. GOODFELLOW,${ }^{2 *}$ D. E. MINNIKIN, ${ }^{3}$ \\ S. MEGAN MINNIKIN ${ }^{3}$ AND IWONA G. HUTCHINSON \\ ${ }^{1}$ Institute of Medical Microbiology, University of Göteborg, Göteborg, Sweden \\ ${ }^{2}$ Department of Microbiology, The University, Newcastle upon Tyne NE1 7RU,U.K. \\ ${ }^{3}$ Department of Organic Chemistry, The University, Newcastle upon Tyne NE1 7RU, U.K.
}

(Received 26 May 1981)

\begin{abstract}
Comparative immunodiffusion studies and thin-layer chromatographic analyses of wholeorganism acid methanolysates were performed on 37 strains of Mycobacterium farcinogenes, Mycobacterium senegalense and Nocardia farcinica. The latter were clearly distinguished from the mycobacteria in containing a single mycolic acid methyl ester and showing more precipitinogens with nocardial than with mycobacterial and rhodococcal reference systems. The distribution of precipitinogens showed that $M$. farcinogenes and $M$. senegalense were very closely related and that both showed a greater affinity to Mycobacterium fortuitum than to any of the other established species of Mycobacterium tested. The complex pattern of $\alpha$-mycolates and characteristic polar mycolates found in both $M$. farcinogenes and $M$. senegalense has only previously been found in M. fortuitum and Mycobacterium smegmatis.
\end{abstract}

\section{INTRODUCTION}

The application of modern taxonomic methods has clarified relationships within and between the genera Mycobacterium and Nocardia, and has led to improved circumscription of these taxa (Bradley, 1973, 1975; Lechevalier, 1976; Goodfellow \& Minnikin, 1977, 1981, 1982; Goodfellow \& Wayne, 1982; Mordarski et al., 1977, 1978; Minnikin \& Goodfellow, 1980; Lind \& Ridell, 1982). A number of taxonomic problems do, however, remain and these include the status and relationships of the taxa Nocardia farcinica, Mycobacterium farcinogenes and Mycobacterium senegalense.

Strains originally labelled $N$. farcinica fall into at least two distinct groups, one of which encompasses the causal agent of bovine farcy. Thus, strains such as $N$. farcinica ATCC 3318 are closely related to Nocardia asteroides (Gordon \& Mihm, 1959, 1962 a; Ridell, 1975; Schaal \& Reutersberg, 1978; Williams et al., 1980), whereas others, such as NCTC 4524, a strain supposedly identical to ATCC 3318 , have many properties in common with mycobacteria and are now classified accordingly (Anderson \& Bradley, 1961; Chamoiseau \& Asselineau, 1970; Lanéelle et al., 1971; Lechevalier et al., 1971; Ridell \& Norlin, 1973; Ridell, 1975; Magnusson, 1976; Collins et al., 1977; Orchard \& Goodfellow, 1980). Gordon \& Mihm (1962a) were unable to separate $N$. farcinica ATCC 3318 from typical strains of $N$. asteroides but, in contrast, Magnusson \& Mariat (1968) found this and related strains to be clearly distinguishable from $N$. asteroides. In a subsequent study, Tsukamura (1969) recovered strain ATCC 3318 in a homogeneous phenon that was designated $N$. farcinica Trevisan.

Chamoiseau (1973) introduced the taxon Mycobacterium farcinogenes, and recognized two subspecies, tchadense and senegalense, each of which accommodated strains able to cause 


\section{Table 1. Designation and sources of test strains}

M260 Mycobacterium farcinogenes; M. P. Lechevalier, Rutgers University, New Brunswick, U.S.A.; Institut Pasteur (IP) 736; bovine farcy, Farcha Laboratory, Fort Lamy, Chad; M. Ridell, N166

M261 M. farcinogenes; M. P. Lechevalier; IP 740; bovine farcy, Farcha Laboratory, Fort Lamy, Chad; M. Ridell, N167

*M262 M.farcinogenes; M. P. Lechevalier; M. Goodfellow; NCTC 10955; M. Ridell, N168

M269 M. farcinogenes; E. H. Runyon, Tuberculosis Research Institute, Pretoria, South Africa, R422; IP 735; bovine farcy, Farcha Laboratory, Fort Lamy, Chad; M. Ridell, N204

M271 M. farcinogenes; E. H. Runyon, R415; R. E. Gordon, 1226; bovine farcy, Farcha Laboratory, Fort Lamy, Chad; M. Ridell, N193

M272 M. farcinogenes; E. H. Runyon, R425; IP 738; bovine farcy, Farcha Laboratory, Fort Lamy, Chad; M. Ridell, N194

M273 M. farcinogenes; E. H. Runyon, R414; IP 739; bovine farcy, Farcha Laboratory, Fort Lamy, Chad; M. Ridell, N212

M275 M. farcinogenes; E. H. Runyon, R427; IP 742; bovine farcy, Farcha Laboratory, Fort Lamy, Chad; M. Ridell, N213

M276 M. farcinogenes; E. H. Runyon, R428; IP 743; bovine farcy, Farcha Laboratory, Fort Lamy, Chad; M. Ridell, N195

M277 M. farcinogenes; E. H. Runyon, R429; IP 744; bovine farcy, Farcha Laboratory, Fort Lamy, Chad; M. Ridell, N 196

M280 M. farcinogenes; E. H. Runyon, R 147; P. Perreau, MA 75; M. Ridell, N214

N709 M. farcinogenes; M. Ridell, BF1; R. E. Gordon, 1223; bovine farcy, Farcha Laboratory, Fort Lamy, Chad

N711 M. farcinogenes; M. Ridell, BF3; R. E. Gordon, 1242; bovine farcy, Farcha Laboratory, Fort Lamy, Chad

N715 M. farcinogenes; M. Ridell, BF7; M. P. Lechevalier, 1224; bovine farcy, Farcha Laboratory, Fort Lamy, Chad

N716 M. farcinogenes; M. Ridell, BF8; M. P. Lechevalier, 1243; bovine farcy, Sudan

N720 M. farcinogenes; M. Ridell, BF 13; M. P. Lechevalier, 1244; bovine farcy, Sudan

M259 Mycobacterium senegalense; M. P. Lechevalier; M. Goodfellow, W34; NCTC 4524; M. Ridell, N165

*M263

M265

M. senegalense; M. P. Lechevąlier; M. Goodfellow; NCTC 10956; M. Ridell, N169

M. senegalense; E. H. Runyon, R408; R. E. Gordon, 1361; IP 397; bovine farcy, Dakar, Senegal; M. Ridell, N 184

M279 M. senegalense; E. H. Runyon, R148; P. Perreau, MA378; M. Ridell, N180

M282 M. senegalense; E. H. Runyon, R455; P. Perreau, D1; M. Ridell, N 176

M283 M. senegalense; E. H. Runyon, R456; P. Perreau, D2; M. Ridell, N177

N696 M. senegalense; M. Ridell, N33; I. Juhlin, 396/193

N712 M. senegalense; M. Ridell, BF4; R. E. Gordon, 1360, 5702; IP 396; bovine farcy, French West Africa

N714 M. senegalense; M. Ridell, BF6; R. E. Gordon, 1363, 434C; bovine farcy, Dakar, Senegal

N721 M. senegalense; M. Ridell, BF 14; M. P. Lechevalier, 931; bovine farcy, Dakar, Senegal

N723 M. senegalense; M. Ridell, N56; R. N. Bönicke, SN5701

N727 M. senegalense; M. Ridell, N122; M. Magnusson, 875; bovine farcy, Dakar, Senegal

N728 M. senegalense; M. Ridell, N123; M. Magnusson, 876; isolated from same animal as N727

N729 M. senegalense; E. H. Runyon, 410; R. E. Gordon, 1364; M. Ridell, N124

*M258 Nocardia farcinica; M. P. Lechevalier; ATCC 3318; M. Ridell, N164

*N699 N. farcinica; M. Ridell, N58; R. N. Bönicke, EB 1957; ATCC 3318

*N700 N. farcinica; M. Ridell, N66; M. Magnusson, 752; R. E. Gordon; ATCC 3318 ( N. asteroides)

N701 N. farcinica; M. Ridell, N67; M. Magnusson, 753; ATCC 3399 ( N. asteroides)

N704 N. farcinica; M. Ridell, N118; M. Magnusson, 654; ATCC 6864, NCTC 1935; isolated from a rabbit, East Sumatra, 1925

N705 N.farcinica; M. Ridell, N119; M. Magnusson, 844; isolated from a case of nocardiosis in Sweden

N707 N.farcinica; M. Ridell, N125; M. Magnusson, 878

* Type strain.

bovine farcy (Chamoiseau, 1969, 1972). The subspecies were subsequently raised to species status as Mycobacterium farcinogenes and Mycobacterium senegalense, respectively (Chamoiseau, 1979). Strains of the latter when compared with the former are rapid-growers as opposed to slow-growers, are more active biochemically, contain a characteristic mycoside C, cause a more generalized peritonitis in guinea pigs, but do show appreciable DNA homology with $M$. farcinogenes. Little is known of the relationships of $M$. farcinogenes and $M$. senegalense to established Mycobacterium species, though the agents of bovine farcy can be 
distinguished by their characteristic pathogenicity for guinea pigs, ability to form a stable mycelium and positive malonamidase reaction (Chamoiseau, 1979). Preliminary immunodiffusion (Ridell et al., 1979) studies indicate an affinity between the bovine farcy organisms and Mycobacterium fortuitum and Mycobacterium smegmatis.

In the present study, representatives of $M$. farcinogenes, $M$. senegalense and $N$. farcinica were the subject of comparative immunodiffusion and lipid analyses designed to determine the relationships of these taxa to one another and to related actinomycetes.

\section{METHODS}

Strains. The sources of the 37 strains included in both the immunodiffusion and lipid analyses are given in Table 1. In addition, ten representative strains of the genus Mycobacterium, two of Nocardia and one of Rhodococcus (see Tables 2 and 3 ) were included in the serological analyses for comparative purposes.

Analysis of long-chain components. The test strains were maintained on glucose yeast extract agar at room temperature (Gordon \& Mihm, 1962b). Biomass for the lipid analyses was prepared by growing organisms in shake flasks of modified Sauton's medium (Mordarska et al., 1972) for 7-14 d at $30^{\circ} \mathrm{C}$. The strains were checked for purity at maximum growth, killed with formaldehyde $(1 \%, v / v)$, harvested by centrifugation, washed with distilled water and freeze-dried.

Freeze-dried bacteria $(50 \mathrm{mg})$ were degraded by treatment at $75^{\circ} \mathrm{C}$ with a mixture $(3 \mathrm{ml})$ of methanol/ toluene/sulphuric acid (30:15:1, by vol.) for $16 \mathrm{~h}$ (Minnikin et al., 1980). Long-chain components were extracted with two portions of petroleum ether (b.p. $60-80^{\circ} \mathrm{C}$ ) and traces of acid were removed by passage through a short column of ammonium hydrogen carbonate. Thin-layer chromatographic (t.l.c.) analyses of the extracts were performed on $10 \times 10 \mathrm{~cm}$ pieces of Merck 5554 silica gel $60 \mathrm{~F}_{254}$ aluminium sheets or on $20 \times 30 \mathrm{~cm}$ layers $(0.5 \mathrm{~mm})$ of Merck 7739 silica gel $60 \mathrm{HF}_{254}$. Chromatography in a single dimension involved a single development with petroleum ether/acetone $(95: 5$, by vol.); for two-dimensional analysis, a triple development with the same mixture in the first direction was followed by a single development with toluene/acetone ( $97: 3$, by vol.) (Minnikin $e t$ al., 1980) in the second direction. Separated components were revealed on aluminium-backed sheets by heating at $120^{\circ} \mathrm{C}$ for $15 \mathrm{~min}$ after spraying with $10 \%$ ethanolic molybdophosphoric acid, while for layers spread on glass, spraying with $50 \%$ aqueous sulphuric acid was followed by charring at $180^{\circ} \mathrm{C}$ for $20 \mathrm{~min}$.

Comparative immunodiffusion analyses. Antigens were prepared from extracts of disintegrated cell mass as described previously (Ridell \& Norlin, 1973). Thirteen reference precipitation systems (Table 2) were employed including those prepared from the type strains of $M$. farcinogenes (M262, NCTC 10955) and M. senegalense (M263, NCTC 10956), and from $M$. senegalense M696. The other ten reference systems and the methods employed for their preparation have been described previously (Ridell \& Norlin, 1973; Ridell, 1975; Ridell et al., 1979). The serological analyses were performed using a microplate modification (Wadsworth, 1962) of the immunodiffusion technique of Ouchterlony $(1958,1962)$. For each combination of test antigen and reference antiserum, two results were recorded: the first figure represents the total number of precipitation lines obtained in the reaction between the test antigen and the reference antiserum; the second figure represents the number of precipitinogens of the test antigen that could be identified by means of the reference system (Ridell, 1975; Ridell $e t$ al., 1979).

\section{RESULTS \\ Analysis of long-chain components}

Single-dimensional t.l.c. of whole-organism acid methanolysates of the test strains (Table 1) indicated that the patterns of long-chain compounds from the $N$. farcinica strains were clearly distinct from those of $M$. farcinogenes and $M$. senegalense. Two-dimensional t.l.c. gave more precise separation of all of the components: representative examples, for $N$. farcinica M258 (ATCC 3318), M. farcinogenes M262 (NCTC 10955) and $M$. senegalense M263 (NCTC 10956) and N723, are given in Fig. 1. All of the $N$. farcinica strains (Table 1) gave simple patterns similar to that shown for strain M258 (Fig. 1). Such a pattern, consisting of non-hydroxylated fatty acid methyl esters, single mycolic acid methyl ester components, and occasionally characteristic long-chain alcohols (nocardols), is characteristic of Nocardia sensu stricto (Minnikin \& Goodfellow, 1976, 1980; Minnikin et al., 1980). The proportion of nocardols was highest in strain M258 but significant amounts were detected in the methanolysates from other strains. 

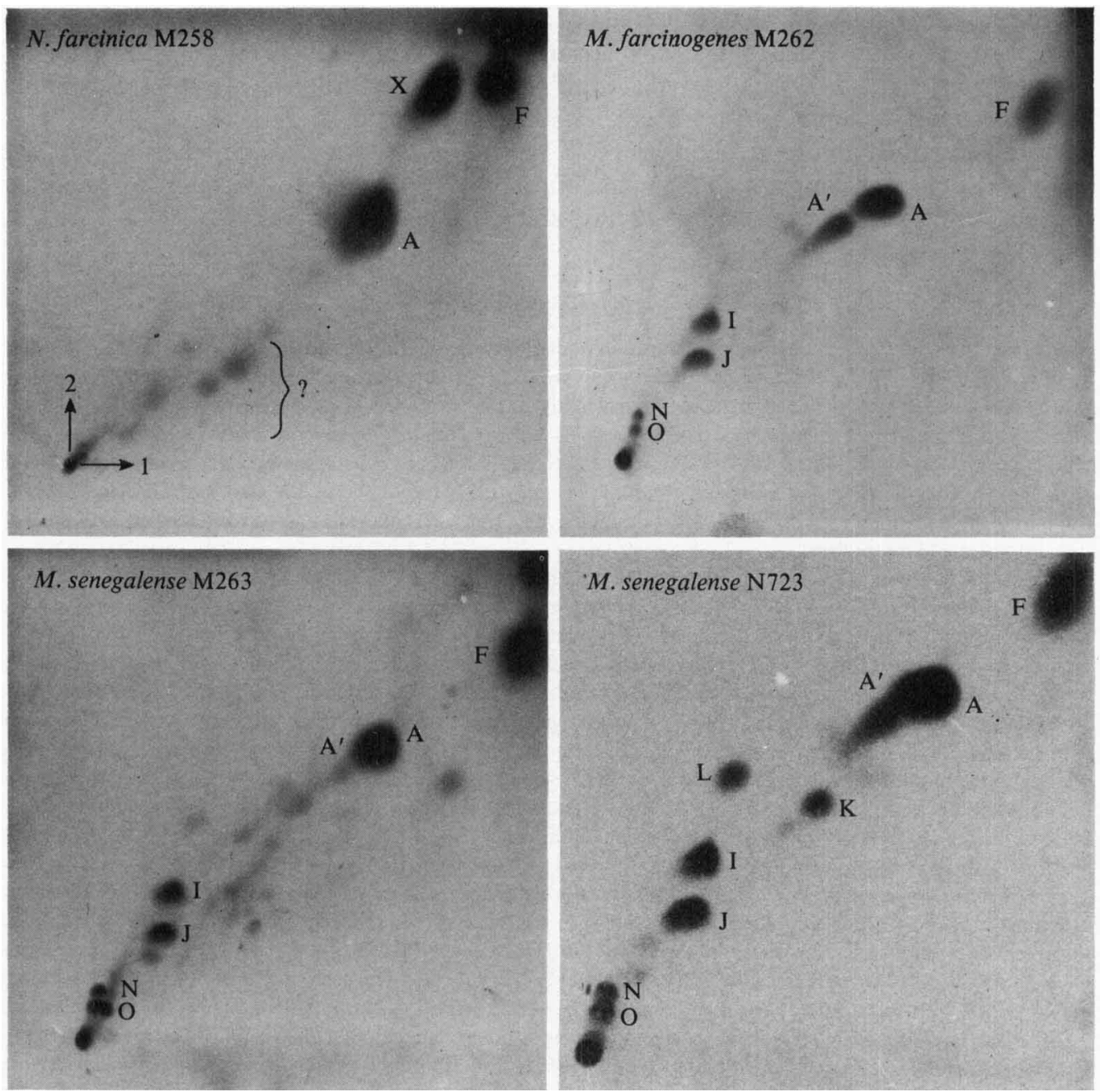

Fig. 1. Two-dimensional t.l.c. of whole-organism acid methanolysates of $N$. farcinica M258 (ATCC 3318), M. farcinogenes M262 (NCTC 10955), M. senegalense M263 (NCTC 10956) and $M$. senegalense N723. A triple development with petroleum ether (b.p. $\left.60-80^{\circ} \mathrm{C}\right) /$ acetone $(95: 5, \mathrm{v} / \mathrm{v})$ in the first direction was followed by a single development with toluene/acetone $(97: 3, v / v)$ in the second direction. Abbreviations: $\mathrm{F}$, non-hydroxylated fatty acid methyl esters; $\mathrm{X}$, possible long-chain alcohol ('nocardol'); A, $\alpha$-mycolate; A', possible $\alpha^{\prime}$-mycolate; I, J, K, L, N, O, unknown long-chain components; ?, unidentified minor components.

All the strains (Table 1) of both $M$. farcinogenes and $M$. senegalense had general patterns of long-chain compounds similar to those recorded for the type strains M262 (NCTC 10955) and M263 (NCTC 10956) (Fig. 1), and copies of these have been deposited with the British Library Lending Division, Boston Spa, Yorkshire LS23 7BQ, as Supplementary Publication No. SUP 28013 (5 pages). (Copies may be obtained from the BLLD on demand; wherever possible, requests should be accompanied by prepaid coupons, held by many university and technical libraries and by the British Council.)

The principal long-chain components present in $M$. farcinogenes and $M$. senegalense (Fig. 1) co-chromatographed with non-hydroxylated fatty acid methyl esters and mycolic esters similar to those found in methanolysates of $M$. fortuitum and $M$. smegmatis (Minnikin et al., 1980). The least polar mycolates (A, A'; Fig. 1) are considered to be the so-called $\alpha$ - and 


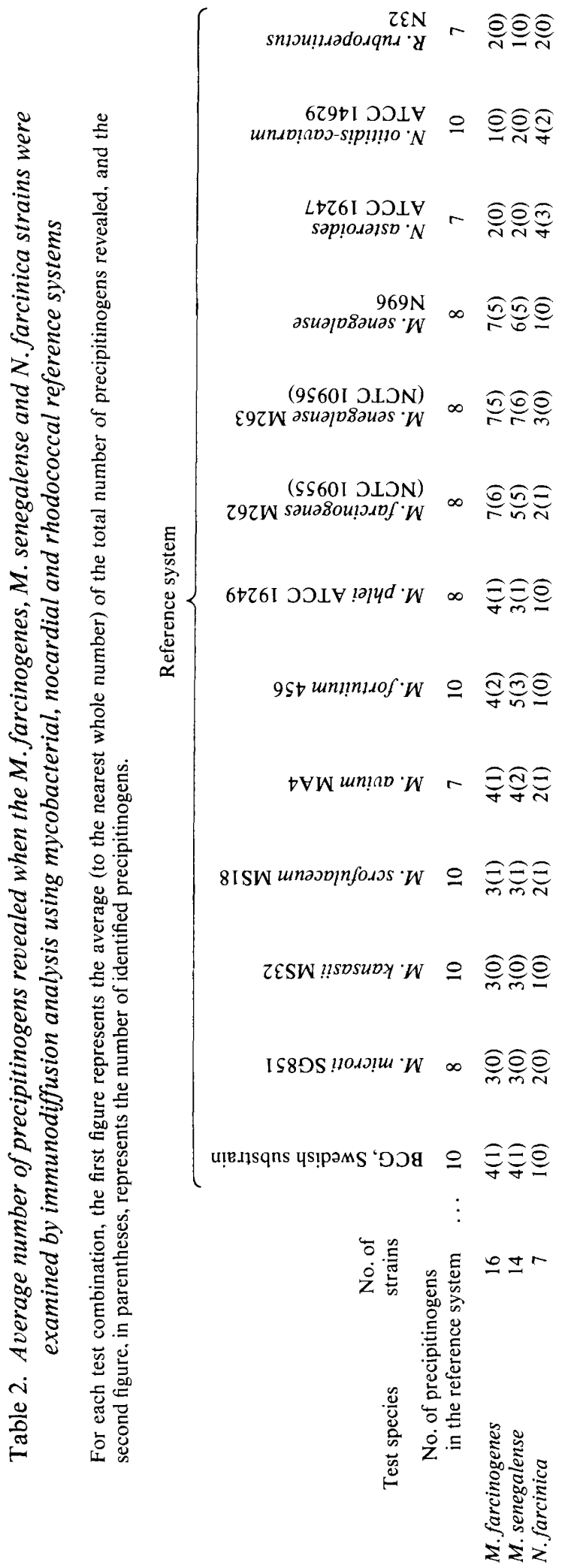


Table 3. Number of precipitinogens revealed when ten representative mycobacteria were examined by immunodiffusion analysis using one $M$. farcinogenes and two $M$. senegalense reference systems

For each test combination, the first figure represents the total number of precipitinogens revealed, and the second figure, in parentheses, represents the number of identified precipitinogens.

\begin{tabular}{|c|c|c|c|}
\hline \multirow{2}{*}{ Test strain } & \multicolumn{3}{|c|}{ Reference system } \\
\hline & $\begin{array}{c}\text { M. farcinogenes } \\
\text { M262 (NCTC 10955) }\end{array}$ & $\begin{array}{c}\text { M. senegalense } \\
\text { M263 (NCTC 10956) }\end{array}$ & $\begin{array}{c}\text { M. senegalense } \\
\text { N696 }\end{array}$ \\
\hline $\begin{array}{l}\text { No. of precipitinogens in } \\
\text { the reference system }\end{array}$ & $\cdots$ & 8 & 8 \\
\hline BCG, Swedish substrain & $3(1)$ & $3(1)$ & $2(1)$ \\
\hline M. microti SG851 & $2(0)$ & $1(1)$ & $0(0)$ \\
\hline M. kansasii ATCC 25221 & $3(1)$ & $3(1)$ & 1(1) \\
\hline M. scrofulaceum ATCC 25214 & $3(1)$ & $3(2)$ & $0(0)$ \\
\hline M. avium ATCC 19421 & $4(2)$ & $3(0)$ & $2(1)$ \\
\hline M. fortuitum АТCC 6841 & $6(4)$ & $6(4)$ & $6(5)$ \\
\hline M. parafortuitum ATCC 19686 & $4(1)$ & $3(1)$ & $4(1)$ \\
\hline M. phlei ATCC 19249 & $4(2)$ & $6(3)$ & $4(0)$ \\
\hline M. smegmatis ATCC 14468 & $6(3)$ & $4(3)$ & $6(3)$ \\
\hline M. vaccae ATCC 15483 & $4(1)$ & $3(1)$ & $4(1)$ \\
\hline
\end{tabular}

$\alpha^{\prime}$-mycolates (Etémadi, 1967) which lack oxygen functions apart from the 3-hydroxy ester unit. The other most characteristic long-chain components found in all the methanolysates of $M$. farcinogenes and $M$. senegalense are the pairs of polar mycolates (I, J; N, O; Fig. 1) previously found only in M. fortuitum and M. smegmatis (Minnikin \& Goodfellow, 1980; Minnikin et al., 1980). In certain strains other minor long-chain components were observed, the most prominent being those $(\mathrm{K}, \mathrm{L})$ found in $M$. senegalense N723 (Fig. 1) which correspond in chromatographic behaviour to components detected previously in acid methanolysates of $M$. fortuitum and $M$. smegmatis (Minnikin et al., 1980). Component $\mathrm{K}$ also appeared to be present in the methanolysates of $M$. senegalense M283, N696 and N712 co-occurring with smaller amounts of component $\mathrm{L}$. The latter was also found in fairly significant amounts in methanolysates of $M$. farcinogenes M271, M272, M277, N709, N711, N715, N716 and N720 and to a lesser degree in M. farcinogenes M269, M273 and M280 and in $M$. senegalense N721, N727, N728 and N729.

\section{Comparative immunodiffusion analyses}

The 37 test strains were analysed by the comparative immunodiffusion technique employing ten mycobacterial, two nocardial and a single rhodococcal reference system (Table 2). The average numbers of precipitinogens shared by the test and reference strains are shown in Table 2. The $M$. farcinogenes and $M$. senegalense strains shared a higher number of precipitinogens with the mycobacterial reference strains than with the nocardial and rhodococcal ones; in contrast, the $N$. farcinica strains shared the most precipitinogens with the nocardial reference strains. The largest numbers of identified precipitinogens, either five or six, were observed when the $M$. farcinogenes and $M$. senegalense strains were analysed with the three corresponding reference systems, the next highest numbers being observed with the $M$. fortuitum reference system.

The numbers of precipitinogens found when representative mycobacteria were analysed with the $M$. farcinogenes and two $M$. senegalense reference systems are shown in Table 3 . The highest numbers of revealed and identified precipitinogens were found in reactions between the type strain of $M$. fortuitum and the three reference systems, though several precipitinogens were also recorded between the latter and $M$. smegmatis ATCC 14468. It is also interesting 
that, in the reaction between Mycobacterium phlei ATCC 19249 and the $M$. farcinogenes M262 (NCTC 10955) and M. senegalense M263 (NCTC 10956) systems, two and three precipitinogens were identified, respectively.

\section{S C US SION}

The $N$. farcinica strains, including the type strain ATCC 3318, were clearly distinguished from both $M$. farcinogenes and $M$. senegalense in the lipid and immunodiffusion analyses. Thus, these strains contained a single mycolic acid methyl ester and non-hydroxylated fatty acid methyl esters characteristic of true nocardiae (Minnikin \& Goodfellow, 1980), and showed more precipitinogens on immunodiffusion with the nocardial reference systems than with the mycobacterial and rhodococcal reference systems (Table 2). These data add weight to the view that $N$. farcinica Trevisan is a good Nocardia species (Tsukamura, 1969; Ridell, 1975; Bradley \& Mordarski, 1976; Orchard \& Goodfellow, 1980).

Mycobacterial mycolates yield a number of characteristic patterns on t.l.c. analysis of whole-organism acid methanolysates (Minnikin \& Goodfellow, 1980). The mycolates of $M$. tuberculosis, consisting of $\alpha$-mycolates, ketomycolates and methoxymycolates, are an example of the first pattern; the second pattern, exemplified by $M$. avium, consists of $\alpha$-mycolates, ketomycolates, $\omega$-carboxymycolates and 2 -eicosanol; in the third pattern, $\alpha$ - and $\alpha^{\prime}$-mycolates co-occur with characteristic unknown polar mycolates, as found for acid methanolysates of $M$. fortuitum and $M$. smegmatis (Minnikin et al., 1980); finally, $M$. chelonei strains give a very simple mycolate pattern of two spots which correspond to a diunsaturated $\alpha$-mycolate and lower molecular weight $\alpha^{\prime}$-mycolate (Minnikin et al., 1982). The principal long-chain components of the $M$. farcinogenes and $M$. senegalense strains co-chromatographed with methyl mycolates and non-hydroxylated fatty acid methyl esters similar to those found in $M$. fortuitum and $M$. smegmatis. On the basis of the lipid data, therefore, $M$. farcinogenes and $M$. senegalense cannot be distinguished as each contains $\alpha$-mycolates and characteristic polar mycolates previously only found in $M$. fortuitum and $M$. smegmatis.

The large number of identified precipitinogens demonstrated between the $M$. farcinogenes and $M$. senegalense strains in immunodiffusion analyses shows not only that they are closely related but is consistent with their classification in a single species (Ridell, 1974, 1981). The serological data also show that both the slow-growing $M$. farcinogenes and the fast-growing $M$. senegalense are closely related to $M$. fortuitum, and to a lesser extent to $M$. phlei and $M$. smegmatis, but can readily be distinguished from other established species of Mycobacterium (Tables 2 and 3). These findings are in good agreement with preliminary immunological data (Ridell et al., 1979).

Both lipid and serological data indicate that $M$. farcinogenes and $M$. senegalense are closely related to one another and to $M$. fortuitum. The results of the serological analyses suggest that $M$. farcinogenes and $M$. senegalense might be classified as a single species, whereas t.l.c. analysis of mycobacterial mycolates does not always yield data sufficientiy sensitive for species differentiation. Detailed studies using appropriate modern taxonomic techniques are required to determine whether or not $M$. farcinogenes and $M$. senegalense should remain as separate species.

Recently, Shigidi et al. (1980) isolated 21 strains from cattle with bovine farcy in the Sudan and assigned them to the genus Nocardia on the basis of chemical, physiological and serological criteria. The results of this interesting study need to be confirmed as the taxonomic data do not demonstrate unequivocally that the isolates are nocardiae. Thus, nocardiae and mycobacteria share many physiological properties. They have also several antigens in common and the presence or absence of a single unidentified precipitinogen cannot be used to distinguish between the genera Mycobacterium and Nocardia.

The authors are indebted to colleagues who kindly provided strains (Table 1) and to Vivianne Sundaeus, Carole Todd, Alan Temple and Gun Wallerström for technical assistance. M. R. is grateful for support from the World 
Health Organisation, the Swedish National Association against Heart and Chest Diseases and to Ellen, Walter and Lennart Hesselman's Foundation. M.G. and D.E.M. gratefully acknowledge the support of the Medical Research Council (G974/522/S), D.E.M. and S.M. M. received support from the Science Research Council (GRA 88651), while M. G. thanks the British Council for a travel grant.

\section{REFERENCES}

Anderson, D. L. \& Bradley, S. G. (1961). Susceptibility of nocardiae and mycobacteria to actinophage. Antimicrobial Agents and Chemotherapy, 898.

BradLEy, S. G. (1973). Relationships among mycobacteria and nocardiae based on deoxyribonucleic acid reassociation. Journal of Bacteriology 113, 645-651.

BradLey, S. G. (1975). Significance of nucleic acid hybridization to systematics of actinomycetes. $A d$ vances in Applied Microbiology 19, 59-70.

Bradley, S. G. \& Mordarski, M. (1976). Association of polydeoxyribonucleotides of deoxyribonucleic acids from nocardioform bacteria. In The Biology of the Nocardiae, pp. 310-336. Edited by M. Goodfellow, G. H. Brownell \& J. A. Serrano. London: Academic Press.

Chamoiseau, G. (1969). De l'étiologie du farcin de zébus tchadiens: nocardiose ou mycobactériose? I. Etude bactériologique et biochimique. Revue d'élevage et de médecine vétérinaire des pays tropicaux 22, 195-204.

Chamoiseau, G. (1972). De l'étiologie du farcin de zébus tchadiens: nocardiose ou mycobactériose? III. Activité amidasique. Revue d'élevage et de médecine vétérinaire des pays tropicaux 25, 191-194.

Chamoiseau, G. (1973). Mycobacterium farcinogenes agent causal du farcin du boeuf en Afrique. Annales de Microbiologie 124A, 215-222.

Chamoiseau, G. (1979). Etiology of farcy in african bovines: nomenclature of the causal organisms Mycobacterium farcinogenes Chamoiseau and Mycobacterium senegalense (Chamoiseau) comb.nov. International Journal of Systematic Bacteriology 29, 407-410.

Chamoiseau, G. \& Asselineau, J. (1970). Examen des lipides d'une souche de Nocardia farcinica: présence d'acides mycoliques. Compte rendu hebdomaire des séances de l'Académie des sciences 270D, 2603-2604.

Collins, M. D., Pirouz, T., Goodfellow, M. \& MinNikin, D. E. (1977). Distribution of menaquinones in actinomycetes and corynebacteria. Journal of General Microbiology 100, 221-230.

ETÉMADI, A.-H. (1967). Les acides mycoliques: structure, biogenèse et intérêt phylogénétique. Exposés annuels de biochimie médicale 28, 77-109.

Goodfellow, M. \& MinNikin, D. E. (1977). Nocardioform bacteria. Annual Review of Microbiology 31, 159-180.

Goodfellow, M. \& Minnikin, D. E. (1981). Classification of nocardioform bacteria. Zentralblatt für Bakteriologie, Parasitenkunde, Infektionskrankheiten und Hygiene (Abteilung I), Supplement 11, 7-16.

Goodfellow, M. \& Minnikin, D. E. (1982). Circumscription of the genus. In The Mycobacteria: $A$
Source Book. Edited by G. Kubica \& L. G. Wayne. New York: Marcel Dekker (in the Press).

Goodfellow, M. \& WAYNE, L. G. (1982). Taxonomy and nomenclature. In The Biology of the $\mathrm{Myco}^{-}$ bacteria, pp. 472-521. Edited by C. Ratledge \& J. L. Stanford. London: Academic Press.

Gordon, R. E. \& Mrhm, J. M. (1959). A comparison of Nocardia asteroides and Nocardia brasiliensis. Journal of General Microbiology 20, 129-135.

Gordon, R. E. \& MiнM, J. M. (1962a). The type species of the genus Nocardia. Journal of General Microbiology 27, 1-10.

Gordon, R. E. \& MiHM, J. M. (1962b). Identification of Nocardia caviae (Erikson) nov.comb. Annals of the New York Academy of Sciences 98, 628-636.

lanéelle, G., Asselineau, J. \& Chamoiseau, G. (1971). Présence de mycosides $C^{\prime}$ (formes simplifées de mycoside $C$ ) dans les bactéries isolées de bovins attients du farcin. FEBS Letters 19, 109-111.

LeCheVAliER, M. P. (1976). The taxonomy of the genus Nocardia: some light at the end of the tunnel? In The Biology of the Nocardiae, pp. 1-38. Edited by M. Goodfellow, G. H. Brownell \& J. A. Serrano. London: Academic Press.

Lechevalier, M. P., Horan, A. C. \& Lechevalier, H. (1971). Lipid composition in the classification of nocardiae and mycobacteria. Journal of Bacteriology 105, 313-318.

Lind, A. \& Ridell, M. (1982). Immunological classification: immunodiffusion and immunoelectrophoresis. In The Mycobacteria: A Source Book. Edited by G. Kubica \& L. G. Wayne. New York: Marcel Dekker (in the Press).

Magnusson, M. (1976). Sensitin tests as an aid in the taxonomy of Nocardia and its pathogenicity. In The Biology of the Nocardiae, pp. 236-265. Edited by M. Goodfellow, G. H. Brownell \& J. A. Serrano. London: Academic Press.

Magnusson, M. \& Mariat, F. (1968). Delineation of Nocardia farcinica by delayed type skin reactions on guinea pigs. Journal of General Microbiology 51, 151-158.

Minnikin, D. E. \& Goodfellow, M. (1976). Lipid composition in the classification and identification of nocardiae and related taxa. In The Biology of the Nocardiae, pp. 160-219. Edited by M. Goodfellow, G. H. Brownell \& J. A. Serrano. London: Academic Press.

Minnikin, D. E. \& Goodfellow, M. (1980). Lipid composition in the classification and identification of acid-fast bacteria. In Microbiological Classification and Identification, pp. 189-256. Edited by $M$. Goodfellow \& R. G. Board. London: Academic Press.

Minnikin, D. E., Hutchinson, I. G., Caldicott, A. B. \& Goodfellow, M. (1980). Thin-layer chromatography of methanolysates of mycolic 
acid-containing bacteria. Journal of Chromatography 188, 221-233.

Minnikin, D. E., Minnikin, S. M., Goodfellow, M. \& Stanford, J. L. (1982). The mycolic acids of Mycobacterium chelonei. Journal of General Microbiology 128, 817-822.

MordarsKa, H., Mordarski, M. \& Goodfellow, M. (1972). Chemotaxonomic characters and classifcation of some nocardioform bacteria. Journal of General Microbiology 71, 77-86.

Mordarski, M., SchaAl, K. P., Szyba, K., Pulverer, G. \& TKaCZ, A. (1977). Classification of Nocardia asteroides and allied taxa based upon deoxyribonucleic acid reassociation. International Journal of Systematic Bacteriology 27, 66-70.

Mordarski, M., SchaAl, K. P., TKacz, A., Pulverer, G., Szyba, K. \& Goodfellow, M. (1978). Deoxyribonucleic acid base composition and homology studies on Nocardia. Zentralblatt für Bakteriologie, Parasitenkunde, Infektionskrankheiten und Hygiene (Abteilung I), Supplement 6, $43-51$.

Orchard, V. A. \& Goodfellow, M. (1980). Numerical classification of some named strains of Nocardia asteroides and related isolates from soil. Journal of General Microbiology 118, 295-312.

OUCHTERLONY, Ö (1958). Diffusion-in-gel methods for immunological analysis. I. Progress in Allergy $5,1-78$.

OUCHTERLONY, Ö. (1962). Diffusion-in-gel methods for immunological analysis. II. Progress in Allergy 6, 30-154.

RiDELl, M. (1974). Serological study of nocardiae and mycobacteria by using Mycobacterium pellegrino and Nocardia corallina precipitation reference systems. International Journal of Systematic Bacteriology 24, 64-72.
Ridell, M. (1975). Taxonomic study of Nocardia farcinica using serological and physiological characters. International Journal of Systematic Bacteriology 25, 124-132.

RIDELL, M. (1981). Immunodiffusion studies of some Nocardia strains. Journal of General Microbiology 123, 69-74.

RiDEll, M. \& Norlin, M. (1973). Serological study of Nocardia by using mycobacterial precipitation reference systems. Journal of Bacteriology 113, 1-7.

Ridell, M., BAKER, R., LiNd, A. \& OUChTERLONY, Ö. (1979). Immunodiffusion studies of ribosomes in classification of mycobacteria and related taxa. International Archives of Allergy and Applied Immunology 59, 162-172.

SchaAl, K. P. \& ReutersberG, H. (1978). Numerical taxonomy of Nocardia asteroides. Zentralblatt für Bakteriologie, Parasitenkunde, Infektionskrankheiten und Hygiene (Abteilung I), Supplement 6, 53-62.

Shigidi, M. T. A., Mirghani, T. \& Musa, M. T. (1980). Characterisation of Nocardia farcinica isolated from cattle with bovine farcy. Research in Veterinary Science 28, 207-211.

Tsukamura, M. (1969). Numerical taxonomy of the genus Nocardia. Journal of General Microbiology 56, 265-287.

WADSWORTH, C. (1962). A microplate technique employing a gel chamber compared with other micro- and macrotechniques for immune diffusion. International Archives of Allergy and Applied Immunology 21, 131-137.

Williams, S. T., Wellington, E. M. H. \& Tipler, L. S. (1980). The taxonomic implications of the reactions of representative Nocardia strains to actinophage. Journal of General Microbiology 119 , 173-178. 